\title{
Reviewing Business Method Patents (BMP's): A Strategic Asset For Companies And Inventors
}

Jwalant Dholakia, (Email: Jd78605w@pace.edu), Pace University

\begin{abstract}
Ever since the State Street Bank decision by the Court of Appeals for the Federal Circuit, BMP's have been validated as patentable subject matter and as a consequence have become a point of discussion and debate among professionals in the industry. Along with this, criticism for the validity and advantages of BMP's has also increased, especially in the wake of some "Bad Patents" granted by the USPTO immediately after the State Street Decision. This paper contradicts this opinion and tries to reinforce the significance and advantages of awarding BMP's to companies in today's global marketplace. BMP's are here to stay. Some fine tuning of its rules and regulations over time might make them more beneficial and efficient; however, it is definite that implementation and use of BMP's is sound policy. The necessary groundwork is laid by conducting a review of the various topics involved while dealing with BMP's including, history, example cases, advantages, legal requirements and procedures, and international aspects among others. This paper should be used as a comprehensive review for conducting an introductory research on BMP's. An interested researcher can look at the USPTO website on BMP's for more detailed and specific information pertaining to various aspects of BMP's.
\end{abstract}

\section{INTRODUCTION \& HISTORY}

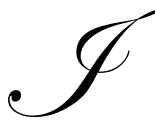

n September 1833, Benjamin Day, a twenty-three year old publisher released the first edition of a new newspaper called the New York Sun. Other newspapers in the market at that time were selling for 5 to 6 cents a piece when Benjamin Day started selling his newspaper for a mere penny. He could manage to sell at that price because of a brilliant idea he came up with. An idea to generate revenue not only from end-readers who pay for the paper, but also from selling space in the paper for advertisements. Also, he revolutionized the paper distribution channels by selling local newsboys in bulk who then roamed the streets to sell it to customers. (Surowiecki, 2003)

This fundamental innovation led in increased sales and rapid growth of the New York Sun and it became one of the leading newspapers in the New York region at that time. However, the one thing he did not do was to patent his innovative ideas and soon other newspapers like the Herald in New York, and some others in Boston and Baltimore came up with similar revenue and distribution models to take advantage of the new ideas. (Surowiecki, 2003)

Historically this has been the situation in American business, where entrepreneurs come up with new business ideas and if they succeed, are soon followed by a number of competitors imitating the business idea and trying to get a piece of the pie. A recent example of this can be that of Netflix Inc., the success of which was followed by entry of Industry leaders like Blockbuster and Walmart (which has now merged with Netflix for their Mail-in-DVD segment) in the Mail-in-DVD market. With growing competition entrepreneurs have come to understand the significance of their business ideas as an Intellectual Property (IP) and their right to use it exclusively as any other form of personal property. 
Nowadays, companies have been making sure that they have their IP protection in place even before they implement a new business idea in practice. This provides the companies legal protection against infringing parties and a legal right to use their IP exclusively. With the advent of Information Technology, old business methods that have been in practice for hundreds of years are now being implemented digitally and there is a huge increase in innovators trying to patent these business ideas. This trend began in 1998, when the United States Court of Appeals for the Federal Circuit approved a Patent application for a method of calculating a "Net Asset Value for Mutual Funds" in the State Street Bank Decision, 149 F. 3d 1368 (1998) (discussed in more detail later). Until then, the United States Patent and Trademark Office (USPTO) rarely granted patents to business methods. The USPTO claimed that business methods were abstract ideas, which did not meet the criteria set for utility patents and therefore they were not patentable. Same methodology was applied in case of software and was also deemed unpatentable. Other prominent examples of classic BMP's include the following:

Amazon.com 1-click Patent (Patent no. 5,960,411) - this case generated a lot of publicity and brought BMP's to everybody's attention. Amazon.com obtained a patent for their unique method of online shopping in which returning customers could buy articles from their website by a single click of the mouse button (without having to reenter order details such as shipping information, credit-card information etc.). Essentially, the novelty that Amazon.com implemented consisted of by-passing the conventional "shopping-cart" method of buying articles from their website for returning customers. (Kirsch, 2001) When competitor, Barnes and Noble also implemented a similar single-click method for returning customers shopping on their website, Amazon.com sued for infringement of their Patent and obtained a preliminary injunction against Barnes and Noble at the District Court Level. The Federal Circuit court also validated the district courts approval to a broad interpretation of the 1-click patent.

Interestingly, to a layperson the 1-Click feature implemented by Amazon.com does not seem to be "nonobvious", which is a requirement for the USPTO (Section 103 of the Patent Act) to grant a patent (More about this in the Legal Requirements Section). For this reason, this patent is notoriously criticized for the technical incompetence showed by the USPTO in granting it. This was later rectified when the Appellate court found that defendant Barnes and Noble raised sufficient concerns regarding validity of the patent and as a result, issuance of preliminary injunction against Barnes and Noble was deemed improper. (Werner, 2005)

The Reverse Auction Patent obtained by PriceLine.com (Patent No. 5,794,207) - This patent is officially defined as "a method and apparatus for a cryptographically assisted commercial network system designed to facilitate buyer-driven conditional purchase offers."

PriceLine.com did not invent the Dutch concept of a reverse auction. However, they got a patent for it, because they were the first to implement it as software on a computer over the Internet. (Werner, 2005) Thus, when travel website Expedia.com later implemented a customer-driven hotel and flight booking model, which essentially allowed customers to bid a price on their website, Priceline sued for infringement of their proprietary business method. Later, this case was settled with Expedia paying licensing fees to Priceline for using the business model on their website.

These are some of the many examples of BMP's granted by USPTO in the years immediately following the State Street decision. Many of these patents do not seem to meet the USPTO requirement for patentable subject matter, specially the non-obviousness requirement. However, on the other side numerous examples also exist of BMP's that are rightfully granted protection as a significant asset for a company. Many of these BMP's are a result of complicated technical, scientific and other industry specific specialized expertise, significant financial investment made in conducting research \& development, and many years of industry experience. It would be unfair if such ideas would not be given protection as a strategic asset for a company, like any other type of company assets. 


\section{PROMINENT EXAMPLE CASES} Software:

What follows are the two key cases which led the USPTO to grant patent rights for Business Methods and

State Street Bank \& Trust Company V. Signature Financial Group, Inc. - Decided on July 23, 1998 by the United States Court of Appeals on the Federal Circuit, 149 F. 3d 1368 (1998), this case set the benchmark for patentability of Business Methods. The court held that:

(...) the transformation of data, representing discrete dollar amounts, by a machine through a series of mathematical calculations into a final share price, constitutes a practical application of a mathematical algorithm, formula, or calculation, because it produces "a useful, concrete and tangible result -- a final share price momentarily fixed for recording and reporting purposes and even accepted and relied upon by regulatory authorities and in subsequent trades.

Essentially, since the decision, it is possible to patent an invention in the United States as long as the invention produces some practical application and has a "useful, concrete and tangible" result whether or not the invention needed the aid of a computer. With this one decision the court validated both software patents and BMP's.

Since the decision there has been a huge increase in the number of applications for BMP's and Software Patents to the USPTO. The USPTO reports that in 1998 there were 1340 Class 705 (The class under which BMP's are generally filed) applications and out of this 420 were actually issued. In 2000, the number of applications rose dramatically to 7800 and 899 of these were issued (Many patents issued during this year are classified by critics are "Bad Patents"; More on this later). In 2001, the applications continued to increase (8700), however, the number issued actually dropped (433). Since 2001, approximately 6700 applications are received each year out of which around 500 are actually approved. (Davis, Fisher, Oliar, Rigamonti, Smith, \& Zollinger, 2005) The reason for this decline in approved patents is because of the increased concern of USPTO to grant only "quality" patents. This is also discussed in further detail in the section that talks about Recent Developments in BMP's.

Diamond V. Diehr, 450 U.S. 175 (1981) - is another important decision, which led to the current laws governing what is patentable and what is not. In this case, the Supreme Court determined that a machine controlled by a software program is patentable, however, the software, which was an implementation of a mathematical algorithm, was by itself not patentable. The court argued that:

(...) an invention which implements or uses a mathematical formula is different than an invention which claims the formula in the abstract. Thus when the invention as a whole meets the requirements of patentability, the invention satisfies patentable subject matter requirement.

This case set the ground for future cases concerning BMP's as long as they met the USPTO requirements for patentability of "utility, novelty, and non-obviousness." These requirements are discussed in detail in the legal requirements section.

\section{LEGAL REQUIREMENTS}

The USPTO has classified BMP's as qualified if they meet the following four requirements: (Nolo, 2005)

1. The method or software must fall within the classes of patentable subject matter. Anything that is manmade falls within these classes with the exception of: abstract ideas, laws of nature, and natural phenomenon.

2. The invention at issue must be useful. This criterion can be easily satisfied because even a functional purpose will suffice as a valid use of the invention. The only requirement is that it provides some concrete tangible result. 
3. The invention must be novel: This criterion requires that the invention must be new and different in someway from the domain of existing knowledge regarding the subject. The invention must add something genuinely new and unique to the existing knowledge base. The invention is considered new and different if it is distinctive in at least one way from existing knowledge. This existing knowledge is known as "Prior Art" in Patent Industry jargon. Prior Art will include the following: (Fisher \& Zollinger, 2001)

3.1 Any Published material (including patents), made publicly available before the date of the invention or more than one year before application for the invention.

3.2 Any U.S patent with a filing date earlier than the date of the invention

3.3 Any relevant method or process existing publicly before the business method was conceived

3.4 Any public use, sale, or knowledge of the business method more than one year before the patent application is filed.

It should be noted here that, if the invention has been talked about in public, put to public use, or has been published more than a year before filing for a patent with the USPTO, it will flunk on the Novelty test.

4. The invention must be non-obvious: The non-obviousness requirement states that results of the invention or business method must be "new or unexpected" to someone with ordinary skill level in the concerned field or business. In other words, if the results obtained by the method are obvious or expected to a layperson, the method cannot be patented. The non-obviousness test thus bars from protection, many business ideas and concepts that would be otherwise patentable.

Critics have expressed concern regarding the less-than-strict enforcement of this requirement while granting some past patents. An example of this is the IBM patent (U.S Patent No. 6,329,919) issued on December 11, 2001 entitled "System and Method for Providing Reservations for Restroom Use." The broadest claim of this patent is as follows: "A method of providing reservations for restroom use, comprising: receiving a reservation request from the user; and notifying the user when the restroom is available for his or her use."

Although IBM has now disclaimed this patent, it serves as a good example of the invalidity of many BMP's.

\section{TIMELINE FOR OBTAINING A BMP}

It usually takes two and a half to three years from the date of filing to obtain a BMP. The period until when the patent is obtained is known as the "Pendency period." The patent owner cannot stop a competitor from using his patent if the competitor stumbled upon it accidentally or even if he is using it on purpose, until the patent is actually granted. Validity for a BMP is for 17 years from date of issue. (Nolo, 2005)

\section{ALTERNATIVE PROTECTION STRATEGIES}

An inventor can also choose to protect his business method as a Trade Secret. The advantage of a Trade Secret is that no formal filing or application is required for protection. Also, protection for a Trade Secret is for lifetime. (Nolo, 2005) Obtaining a Patent for the same invention would be a much more expensive alternative. If the Business Method for which the patent is being obtained is going to be a process which is internal to the organization and transparent to outside people, customers and competitors, the business process might well be used as a trade secret. If this is not the case, obtaining a Patent might be a better idea.

On the other hand, the advantages of getting a patent are many. For one, the patent owner can legally prevent his competitors from practicing his business method even if the competitors developed the method on their own, without stealing or copying from the patent owner. Also, the patent owner can publicly use or license his method to others without loosing his patent rights in the process. (Nolo, 2005) 


\section{BMP'S: WHY ARE THEY IMPORTANT?}

\section{Analysis And Synthesis}

Traditionally, companies involved in production and distribution of goods and services have been an allencompassing institution, dealing with all aspects involved in getting the goods or services from manufacturer to end consumer. These might include investment in research \& development, procuring raw materials, logistics and supply chain management, manufacturing, marketing, recruiting, customer relationship management, public and governmental relations, and this list can go on.

With the advent of technology however, markets have become increasingly competitive and it has become extremely important for companies to specialize. They need to be aware of what their Core Competency is and focus on that to deliver a top quality product in a market environment marked by the effects of globalization and competition. In such an environment, the IP of a company has gained significant importance. This is true especially in developed countries where markets in various goods and services related industries have saturated completely because of competition. In such highly competitive markets the only way to survive and grow is by focusing on the existing clientele and provide efficient and cost effective solutions through sound use of factors like global supply chain management, international logistics, outsourcing, and strong protection and strategic use of ones Intellectual Property assets.

Intangible assets of a company, which include their Intellectual Property, Intellectual Capital and Goodwill, have gained a far higher percentage of companies net worth in recent years. For example, over a 20 -year period from 1978, intangible assets grew from $20 \%$ to account for more than $73 \%$ of the Standard \& Poor's 500 stock index assets as shown in the figure below. (Ch'ang \& Yastreboff, 2003) Thus for a knowledge-based economy like the US, IP is an asset of prime importance.

Figure 1 - (Ch'ang \& Yastreboff, 2003)

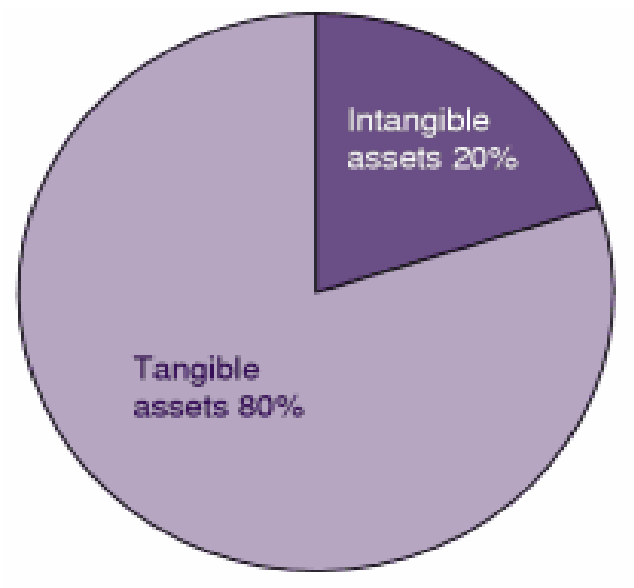

1978

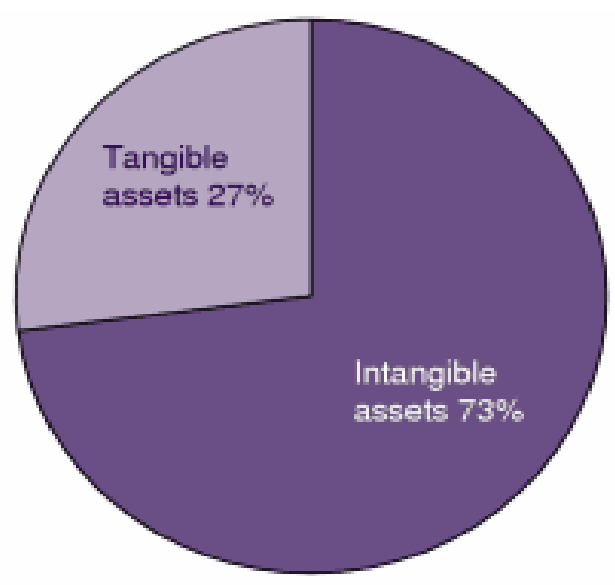

1997

Also, annual revenue generated from IP Licensing fees in the US signifies its importance as a high potential and high growth industry. The US market alone for licensing of IP, which includes software and Business Method patents, approximates to $\$ 45$ billion annually. This figure is close to a $\$ 100$ billion worldwide. (The Economist, October 2005) What follows are a couple of specific company cases showing how they benefited from their IP Portfolio: 
IBM and HP: IBM generated \$1 Billion in licensing and royalties from its IP portfolio last fiscal year. Revenue from the IP portfolio of HP has quadrupled to more than \$200 Million in three years. Many such companies have discovered patents, which have been lying unused in their IP portfolio for many years, going on to generate revenue in millions of dollars through licensing and royalties.

Microsoft: Microsoft, which had filed 8 patents until 1990, is on course to file 3000 patents this year. This change in Microsoft's corporate philosophy towards BMP's and patents in general came about after the 1994 federal court jury verdict for more than $\$ 132$ million in damages to a small software company called Stac Electronics. Microsoft had infringed a software patent owned by the company as a part of its platform product Microsoft Windows Operating System (OS). A potential injunction against the OS product resulted in a settlement between Microsoft and Stac. (Buroker, 2004)

These examples go on to show importance of IP for companies today. And this is true not only for technology companies but for companies in general who are competing in a global marketplace, making use of technology in all aspects of their business process to emerge as a market leader. Especially, the financial industry has recently experienced a huge boom in a move to secure their BMP's and other strategic IP and use it as a competitive tool globally. Some other industries where IP has become a key player include insurance, accounting, risk management, logistics and supply chain management.

Thus, in order to stay competitive in this environment it is important that companies take advantage of their IP rights and keep abreast of constant innovations and changes taking place in the industry. Other reasons why BMP's might be an important asset on a company IP Portfolio briefly include the following:

BMP's can be used both as a sword and as a shield. They can be used as a sword in that the BMP portfolio can be used to generate an alternative revenue stream for the company through licensing and royalties. Also, if a competing company can be legally prohibited from using a BMP of significance, it can be a huge competitive advantage for the company owning the BMP.

An example of this is when Amazon, which had the 1-click patent, was able to obtain a preliminary injunction against its top competitor, Barnes and Noble, from using a similar feature on its website. This happened right at the start of the holiday season and Barnes and Noble was forced to make an immediate modification to its website at a busy time of the year.

On the other hand, BMP's can be used as a shield in that, if Company A owns an BMP and Company B owns a BMP which is similar in context and industry to Company A's BMP, they might be discouraged to sue each other because of the possibility of the non-moving party countersuing the other party on the basis of their BMP. Such a situation might also result in cross-licensing of the IP of the two companies to each other, resulting in a significant competitive advantage.

Also, for startup companies and small sized firms, having a BMP in place might go a long way in helping them seek funding from Venture Capitalists (VC) and Angle Investors, who will have more confidence in the company because of their IP. This is especially true in this day and age, in wake of the post technology boom era when VC funding is extremely hard to find.

Finally, there is a big chance that just as banks created market for capital and insurance firms created a market for risk, it might so happen that granting BMP's might create a market for innovation. This will be of significant advantage to the economy in the long run. (The Economist, October 2005)

\section{PATENT TERRORISM}

As explained in the previous section, IP is without a doubt a sacred asset for American Corporations in this day-and-age. The original purpose of having patent protection in the first place was to stir competition and generate an 
incentive for people to invent new products and commodities. However, with growing use of technology and the increase in granting of BMP's, the incentives of certain people to get their methods patented have changed.

Rather than use a patent as a defensive stratagem, individuals and corporations are acquiring patents for the sole purpose of licensing the method to other companies for percentage-based revenues. Even worse, companies that have acquired patents that are broad enough to sue an entire industry, wait for competitors to use their methods and later extort fees through intimidation and litigation. (Kirsch, 2001)

Immediately after the State Street Bank Decision in 1998, the number of applications to the USPTO for BMP's went up by $40 \%$. At that time, many patent applications were made for various financial and accounting business methods that have been around for hundreds of years, but were deemed patentable because of their application on a computer as software generating a useful result. Many of these patents were later deemed by critics as Bad Patents or Junk Patents, claiming that the USPTO was too liberal in granting these "broadly" applicable patents.

Many organizations with the motive of extorting fees for patent infringement purchased such patents or swallowed companies that were going to acquire such patents. Such organizations neither developed products based on the acquired patents nor retained the original inventors. They then would scour up various companies related to the business areas of the patent and threaten with litigation and infringement to demand high sums of money and royalties. Such practice has been termed "Patent Terrorism."

It should be noted that, as described previously, offering royalties for patent licensing is an old legitimate practice, which generates huge revenue streams for many Fortune 500 companies. However, the moral and ethical violation, in case of Patent Terrorists, is not at issue in this genuine exchange of IP between high-level companies.

A good example of patent terrorism will be a list of patented inventions available for sale by their owners on the popular Internet website ebay.com. For instance, a search done with "phone patent" in the search field shows an invention up for sale for US $\$ 5,000,000$. The posting talks about a mechanism to lock and unlock doors using a cell phone. Such deals, often done through law firms representing the patent owners, have the incentive of making money by suing entire industries claiming infringement, and not for using the invention for development of better technology.

Another recent example of this is the highly publicized Blackberry Case, NTP Inc. v. Research in Motion Ltd. In this case, NTP has sued the Blackberry mobile email service provider, Research In Motion (RIM), a Canada based company, with patent violation claiming licensing revenues on the basis of their total sales till date amounting to 1.5 billion dollars. NTP is a Virginia based holding firm, which owns several Patents in the field of wireless communications and does not actually market its own line of products or use its patents for development purposes. The only source of revenue for NTP seems to be from generating it through licensing and royalty from its patents. It is believed that this case might cots RIM up to 1 billion dollars in fees and licensing costs unless they find a work around for the said technology to provide wireless services to its customers.

\section{INTERNATIONAL PERSPECTIVES}

As previously mentioned, licensing revenues of IP like BMP's and Software Patents is a 100 billion dollar global industry. Therefore, it is important to understand the rules and regulations for obtaining IP protection in various developed and developing countries. What follows is a brief look into these rules and regulations in some of the more important countries from the IP industry perspective:

\section{The European Union}

According to the Articles of the European Patent Convention (EPC), pure Business Methods are not deemed patentable. The European norm is to give patent protection to technical inventions leading to progress in overall technology. Business Methods are looked upon as activities involving buying and selling, marketing, and financial schemes, among others. Therefore, the very idea of business methods signifies an invention of a method, which, by 
definition is non-technical and thus non-patentable. The four-pronged test used by the EPC to determine patentability involves the following: (Engelfriet, 2004)

The Patent is: not excluded by articles 52 (2) and (3) of the EPC, novel, non-obvious (i.e. involves an inventive step), and capable of industrial application.

Accordingly, Business Methods are deemed non-technical and therefore, non-patentable by EPC Article 52 (2) and Article 52 (3) even if they meet other criteria's of patentability. However, due to broad interpretation of the EPC articles many BMP's are, in effect, granted patentability owing to their application as software on a computer (which is considered technical and thus patentable).

\section{Canada}

In Canada, like in Europe, Business Methods do not fall under the umbrella of patentable inventions explicitly. However, if the business method or process can be proven to be inventive enough it might be granted patent rights. Also, if methods have been implemented as technical software on a computer platform, they might be deemed patentable as a whole even if the method by itself is not.

\section{Japan}

The Japanese Patent Office (JPO) has acknowledged the global interest in BMP's and has taken steps to formulate and revise examination standards to develop criteria required for patentability. Also, JPO has taken various steps to make its "Prior Art" databases more exhaustive in order to prevent occurrence of redundant patents, also known as, "Bad Patents", or even worse, exclusion of patents. According to JPO, the essential criteria required for Business Methods and Software to be granted patentability, are: application of a scientific principle, industrial application, and inventive step. (Policy Planning and Research Office, 2000)

\section{China}

With the advent of technology and new Business Method inventions, applications for BMP's are on a continuous rise in China. In 1998, the China State Intellectual Property Office (SIPO) received and approved 577 patents dealing with Business Methods. This number went up to 1,176 in 2000 and around 1,800 in 2002. Most of these patents were proposed for business methods in banking, finance, management, and insurance industries. According to the SIPO website, Chinese Patent Law has determined the following criteria for assessing patentability for BMP's:

1. When the subject matter of the application only involves business method as such (pure business method) and consequently there is no technical character, the subject matter belongs to rules and methods for mental activities. Therefore no patent shall be granted.

2. When the subject matter involves the business methods executed through the adoption of technologies such as network or computer, it is required to determine whether the subject matter "adopts technical means, resolves a technical problem and creates a technical effect" (If the answer is yes, BMP can be granted).

\section{Korea}

Under the Korean Patent Law, in order to be granted protection as a BMP the following three requirements have to be met: novelty, inventiveness, and, industrial applicability.

The requirements are same for BMP's as they are for any other type of Patent. Under the Korean law, pure business methods would not meet the statutory requirements for patentability. However, with careful drafting of the Patent application, rights of a Business Method as a patent can be secured.

(Choung \& Jung, 2003) 


\section{RECENT DEVELOPMENTS}

The concept of BMP's and Software Patents has always been around, however, it was never given a specific focus by the public eye until the 1998 State Street Decision. After this decision, BMP's and Software Patents as a form of IP gained widespread publicity and understanding. This resulted in a huge increase in the number of applications and resultant loss of quality in the years immediately following the State Street Decision. This led to various developments during 2000 and 2001 in this field like the BMP Initiative, Congressional Initiative and the publication of the AIPLA White Paper.

What followed since then until now was a period of dormant activity, with the reason obviously being a downturn in the economy. And the technology industry, which was phenomenal in acquiring BMP's and Software Patents in the late 1990's, was hit the hardest.

Activity has now again started to pickup in the tech industry and consequently, also in the IP industry. This is signified by recent developments in the USPTO like New Guidelines for Patent Subject Matter Eligibility and discontinuation of the Technological Arts requirement, making it easier to get BMP's. Also a recent Supreme Court decision to hear a BMP related case has generated strong interest in the Patent community. What follows is a brief discussion of these developments of the past five years:

\section{The BMP Initiative}

The USPTO has made strong efforts to improve quality of patents for business methods granted by its examiners. This change came about after public criticism over the quality of patents issued by USPTO during a huge increase in number of applications for BMP's in the 2-3 years immediately after the State Street decision. Various strategies and steps were elaborated by USPTO, when in March 2000 it released its BMP Initiative, which deals specifically with Class 705 applications. (Grodin, Sandonato, \& Valdivia, 2002) The initiative was designed to improve Class 705 Patents through industry outreach and quality programs. Some highlights of the specific issues covered under the initiative are as follows: (Alcorn, 2003)

\section{Prior Art Searches}

When an application was made for a BMP to the USPTO, the patent examiners used whatever US and foreign Patents they had available at the Patent Office to determine the Novelty standard for patent applications. However, various other non-patent sources, such as, industry publications, news, and the general media is a possible pool of information that should also be looked at for prior art searches rather than just past patents. This major change was made a mandatory requirement for use while conducting prior art searches.

\section{Qualified Examiners}

At the end of fiscal year 2000, the patent office group handling BMP's had 47 examiners. This increased to 82 in 2001, 130 in 2002 and approximately 160 today. These examiners have data processing and/or computer experience. Also, many of them hold advanced level degrees including PhDs, Law Degrees, Masters Level Degrees and MBA's.

Also, steps are taken to keep the examiners abreast of current ongoing technical industry news and trends through various events and learning programs.

\section{Second-Level Review}

The most important change brought about by the USPTO BMP Initiative is a Second-Level Review for all allowed applications in class 705. Under this system, it is required that a second examiner reviews the application to ensure that the first examiner has properly followed all the rules and regulations set forth as a part of the BMP initiative, while granting or rejecting a BMP on an application. 
These initiatives have led to an improved quality of patents that are granted by the USPTO. Before the initiatives were put in place, 65 to $70 \%$ of BMP's were approved. This number has changed to a rejection rate of 65 to $70 \%$ after they were implemented. (McCullagh, 2002) The initiatives seem to be a right start. However, only time will tell how significant they turn out to be.

\section{Congressional Initiatives}

In April 2001, Democratic representatives Howard Berman from California and Rick Boucher from Virginia had introduced the Business Method Patent Improvement Act of 2001. (Grodin, Sandonato, \& Valdivia, 2002) Although this act was not passed by the congress, it was a culmination of some novel ideas to improve the handling of BMP's by the USPTO. The main purpose of the act was to stop the USPTO from giving out patents that might turn out to be a hindrance to a free development of e-commerce. Some of the proposals included in the act were a requirement that all BMP's be published 18 months after filing and allowing the public to submit relevant prior art to any published applications. The bill also proposed a way to grant the public a more efficient and less expensive way to challenge a BMP after it had already been published.

\section{American Intellectual Property Law Association}

Apart from the above two initiatives, the American Intellectual Property Law Association (AIPLA) has also looked into the issue and published a White Paper in November 2000. This white paper entitled, "Patenting Business Methods", gives various recommendations geared towards improvement of BMP's granted by USPTO.

\section{Subject Matter Eligibility And Discontinuation Of The Technological Arts Requirement}

The Commissioner for Patents at the USPTO, John Doll, in the November 2005 issue of the Official Gazette published the long awaited Patent guidelines entitled Interim Guidelines for Patent Applications for Patent Subject Matter Eligibility. These guidelines do not provide specific subject matter that is eligible for being granted BMP's and subject matter that is not. However, the guidelines do provide the patent examiners with a flowchart containing a categorical list of questions to help determine such patentability. (Dauer Jr, 2005/2006)

Patent Examiners, until now, predominantly relied upon the technological arts test to determine patentability. Under this test, mathematical algorithms, that do not affect machines, such as software programs are not considered patentable. However, this test was considered invalid and was thrown out in a recent case, ex parte Lundgren in October 2005, ruled by the Board for Patent Appeals and Interferences. This means that it would be easier as compared to before to get a BMP.

\section{Supreme Court To Hear BMP Case}

Another important recent development that has attracted attention of the Patent Community is the decision of the Supreme Court of the United States to hear a BMP case. The court granted certiorari in Laboratory Corporation of America Holdings v. Metabolite Laboratories Inc on October 31 2005, which involves patentability of a diagnostic test carried out by doctors. (Mamudi, 2005/ 2006)

In this case, the question that the Court will answer is: "Whether a method patent setting forth an indefinite, undescribed, and non-enabling step directing a party simply to "correlat[e]" test results can validly claim a monopoly over a basic scientific relationship used in medical treatment such that any doctor necessarily infringes the patent merely by thinking about the relationship after looking at a test result." (Mamudi, 2005/ 2006) 
Figure 2 - Flowchart For Patentable Subject Matter Eligibility (Dauer, Jr, 2005/ 2006)

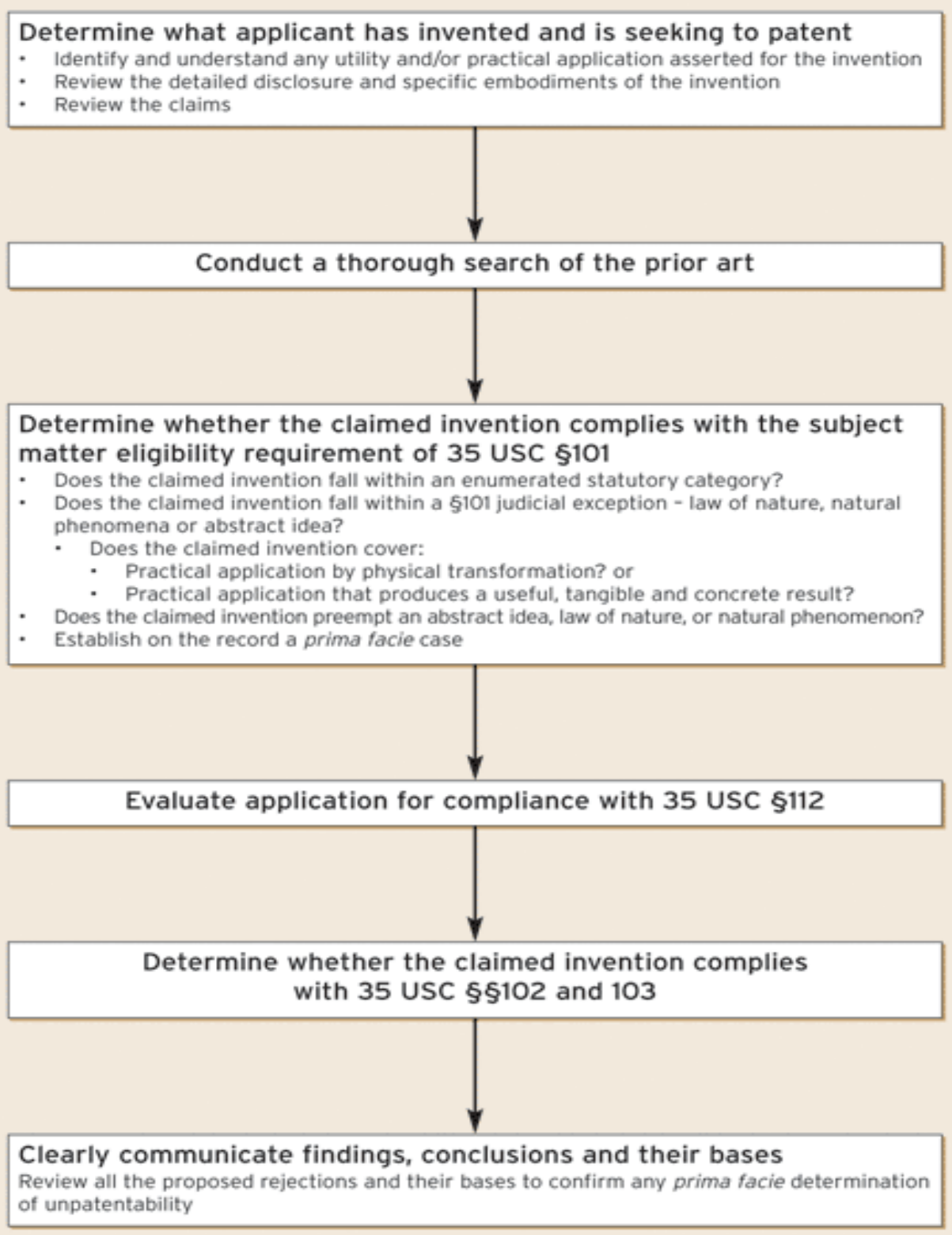

\section{CONCLUSION}

Critics of BMP's have argued that this type of patents are not novel and are "obvious" and should therefore be barred from patent protection. They have mentioned that according to the current laws, every method of doing business can be patented just by implementing it over the Internet. Such a broad interpretation generates "bad patents" which could be used to intimidate companies and to extort large sums in royalties. Such litigations are detrimental to businesses and harm the economy in general. The entire idea of generating healthy competition and promoting innovation is destroyed on the basis of which, the First Congress of the United States originally put the Patent Act in place in 1790. 
Moreover, Lawrence Lessig, a prominent legal scholar and IP expert, has said that BMP's have led to an increase in the cost of Software Development Projects. He also mentions that BMP's impose a huge burden on small businesses, who cannot afford litigation costs which might be generated from "bad patents". Lessig's primary concern is that BMP's and Software Patents threaten the development of the World Wide Web itself. He envisions the Internet being controlled by a few large corporations who get the most BMP's and will monopolize the internet in the process. A proponent of Open Source Software, Lessig feels that software patenting will lead to unnecessarily high software costs and benefits of sharing quality applications developed by open-source programmers will be lost.

However, in spite of these criticisms, the policy for BMP's seems to prevail in the long run. Similar concerns, as discussed above, have always been raised every time an advance in new technology occurs. Even in the past, critics have questioned the appropriateness of patenting automobiles, telephones, pharmaceuticals, and biotechnology. However, with time all concerns raised have died out and the validity of patenting the inventions has prevailed. Hence, it can be suggested that concerns of these critics for BMP's will also die out in the long run. Also the idea that granting of BMP's suppresses innovation is false. By giving protection and exclusive rights to inventors, incentive to invest in projects undertaken to invent new ideas and methods will get a boost. This will also lead to stronger chances of locating financial baking from Venture Capitalists and private investors for startup ventures, who would have not been able to fund their innovative projects otherwise.

Also, with the recent developments like the BMP initiative, many concerns that were raised by industry experts in past have been voiced. Moreover, developments like the Congressional initiative, the AIPLA white paper and the recent decision of the Supreme Court to hear a BMP case show popular interest in the subject and recommend on how to make BMP's more beneficial to the society.

Like any other policy issue, granting of business methods as patents has both advantages and disadvantages for the economy in general. On one hand, BMP's will motivate innovators to come up with new ideas and concepts, which might in turn go a long way in being highly beneficial to the society. BMP's might also turn out to be the most significant strategic asset for companies and inventors. However, on the other hand, if BMP's are granted for every small business method out there just because it is implemented on a computer, it will make the overall use and exchange of IP a very cumbersome procedure. This will lead to increased costs for end users, cross licensing issues, and unnecessary overhead expenditures in licensing every small BMP involved in providing a service which needs use of such business methods. Also, it would lead to increased patent litigations, infringements and increased amounts claimed in damages. Thus, care should be taken to ensure that, in sum, advantages of having BMP's outweigh the disadvantages.

It has only been less than eight years since the concept of BMP's originally came into the limelight in 1998 with the State Street Decision. Also, BMP's predominantly deals with the technology industry, which is extremely fast paced and has only recently started to catch up after suffering a major economic downturn. This makes it difficult to come up with a solid, high-level model to predict the validity and success of BMP's in the long run. It seems more likely than not that; BMP's are here to stay. However, their relevant significance will only be measured over time depending on the quality of BMP's issued by the USPTO, governmental policies, public interest and, most importantly, the kind of approach companies and inventors will have towards use and benefits of BMP's.

\section{REFERENCES}

1. (2003). Patent Protection of New Technologies. China State Intellectual Property Office. Retrieved January 3, 2006, from http://www.sipo.gov.cn/sipo English/gfxx/zyhd/t20031225 33947.htm.

2. Alcorn, L. (2003). Pursuing Business Method Patents in the US Patent and Trademark Office. The Computer \& Internet Lawyer, Volume 20, Number 3.

3. Allison, J. \& Tiller, E. (2002). Internet Business Method Patents. Texas Business Review, October.

4. $\quad$ Ben-Yhuda, R. (2000). Business Method Patents. Law Offices of Sidley Austin Brown \& Wood LLP. Retrieved January 3, 2006, from http://www.sidley.com/cyberlaw/features/bm.asp.

5. Blasey, T. (2000). Business-Method Patents Keep New Economy Clicking. Retrieved January 3, 2006, from http://www.techcentralstation.com/111300H.html. 
6. $\quad$ Bloomberg, M. (2005). Patenting Business. Latin Finance. October 1.

7. Buroker, B. (2004). Business Method Patents: They're Not Just for Dotcom Companies Anymore. Intellectual Property \& Technology Law Journal, Volume 6, Number 9.

8. Canadian BMP Policy. Retrieved January 3, 2006, from http://patents1.ic.gc.ca/intro-e.html.

9. Ch'ang, S. \& Yastreboff, M. (2002/ 2003). How to Identify your Individual Advantage. Managing Intellectual Property, December 2002/ January 2003.

10. Coggins, W. \& Love, J. (2001). Successfully Preparing and Prosecuting a Business Method Patent Application. American Intellectual Property Law Association. Spring. Retrieved January 3, 2006, from http://www.uspto.gov/web/menu/pbmethod/.

11. Dauer, Jr., J. (2005/ 2006). New Guidelines clarify law but lack practicality. Managing Intellectual Property, December 2005/ January 2006.

12. Davis, E., Fisher, W., Oliar D., Rigamonti, C., Smith, A., \& Zollinger, G., Business Method Patents Online Internet Law Program. The Berkman Center for Internet \& Society at Harvard Law School. Retrieved January 3, 2006, from http://cyber.law.harvard.edu/ilaw/harvard 2005 module 7 obmp.

13. European Patent Office. (2000). Patentability of Methods of Doing Business. Retrieved Jan. 3, 2006, from...

14. Fisher, W. \& Zollinger, G. (2001). Business Method Patents Online. The Berkman Center for Internet \& Society at Harvard Law School, Retrieved January 3, 2006, from http://cyber.law.harvard.edu/ilaw/BMP/.

15. Fishman, S. (2002). Web \& Software Development: A Legal Guide. (3rd ed.). Nolo.

16. Friedman, T. (2005). The World is Flat. (1st ed.). Farrar, Straus and Giroux.

17. Goodhue, J. (2004). Purpose of Patenting a Business Method. Retrieved January 3, 2006, from http://www.intelproplaw.com/Articles/cgi/download.cgi?v=1097911060.

18. Grodin, A., Sandonato, M., \& Valdivia, A. (2002). Software and Business Method Patents: A Decade in Review. The Patent Journal. June / July.

19. Gupta, P. \& Michel C. (2005). The Changing Landscape of Business Method Patents; Rush to file following 'State Street Bank' ruling continues, while other decisions this year clarify key issues. The New York Law Journal, October 17. http://www.european-patent-office.org/news/pressrel/2000_08_18_e.htm.

20. Japanese Patent Office. (2000). Policies Concerning "Business Method Patents". Policy Planning and Research Office. Retrieved January 3, 2006, from http://www.jpo.go.jp/tetuzuki_e/t tokkyo_e/tt1211055.htm.

21. Jung, E. \& Choung, A. (2003). How to Secure Business Method Patents in Korea. Institutional Investor PLC, September.

22. Kirsch, G. (2001). What is a "Business-Method Patent"? Retrieved January 3, 2006, from http://www.gigalaw.com/articles/2001-all/kirsch-2001-05-all.html.

23. Kuester, J. (2000). PTO Explains Business Methods Obviousness Standard. Patents Strategy \& Management. Retrieved January 3, 2006, from http://www.kuesterlaw.com/103.htm.

24. Lessig, L. (2000). Online Patents: Leave Them Pending. Wall Street Journal. Retrieved January 3, 2006 , from http://www.lessig.org/content/columns/wsj.pdf.

25. Lytle, B. \& Signore, P. (2003). Finance Companies Rush to Patent Business. Managing Intellectual Property, February.

26. Maclean, P. (2005). Human mind prevails in patent win; Intellectual Property; Business method patents carried out in one's head, without machine, OK'd. The National Law Journal. October 24.

27. Mamudi, S. (2005/ 20006). Supreme Court to hear patent cases. Managing Intellectual Property, December 2005 / January 2006.

28. McCullagh, D. (2002). Are patent methods patently absurd? ZDNet News, October.

29. Mock, D. (2005). The Lowdown on Patent Shakedowns. Retrieved January 3, 2006, from http://www.fool.com/news/commentary/2005/commentary05042605.htm.

30. Newman, M. (2003). EU Weighs Web Patents --- Internet Entrepreneurs Say Ruling on Business Methods Would Favor Large Firms. The Wall Street Journal Europe. September 22.

31. Obtaining a Business Method Patent. Retrieved January 3, 2006, from http://www.nolo.com/article.cfm/ objectID/C2DBFF26-7097-4B7B-AE36DA00499851EE/111/277/167/ART/.

32. Patentability of Business Methods at the European Patent Office - Another website regarding EPC policies, Arnound Engelfriet, January 2004 from http://www.iusmentis.com/patents/businessmethods/epc/.

33. Pearlstein, S. (2005). Lawyers Scare Firms Away From Good Ideas. The Washington Post. February 23. 
34. Pike, G. (2005). Patent Reform Heats Up - Legal Issues. Information Today, July 1.

35. Pressman, D. \& Stim, R. (2004). Nolo's Patents for Beginners (4th ed.) Nolo.

36. Rees, J. (1999). "State Street" Decision Causes “Boom" in Software Patent Filings. Retrieved January 3, 2006, from http://library.findlaw.com/1999/Mar/1/128488.html.

37. Shumaker, S. (2000). Business Method Patents: Navigating a Sea of Controversy. Retrieved January 1, 2006, from http://technolawgy.com/fs_lawyers.asp?page=publicSubList.asp\&categoryId=168\&admin=\&category Name=Patents.

38. Spinello, R. (2003). CyberEthics: Morality and Law in Cyberspace. (2nd ed.). Jones and Bartlett.

39. State Street Bank \& Trust Company V. Signature Financial Group, Inc. Lexis-Nexis Online legal Database. Retrieved December 22, 2005, from http://www.lexisnexis.com/.

40. Surowiecki, J. (2003). Patent Bending. Retrieved January 3, 2006, from http://www.newyorker.com/printables/talk/030714ta talk_surowiecki.

41. The Economist. (2005). A Market for Ideas. The Economist, Print Edition, Oct 20. Retrieved January 3, 2006, from http://www.economist.com/printedition/displaystory.cfm?story id=5014990.

42. University of Texas at Austin. Internet Business Method Patents. Retrieved January 3, 2006, from http://utopia.utexas.edu/articles/tbr/business_patents.html?sec=technology\&sub=infoscience.

43. USPTO White Paper. Automated Financial or Management Data Processing Methods (Business Methods). Retrieved January 3, 2006, from http://www.uspto.gov/web/menu/busmethp/downloads.htm.

44. Werner, C. (2005). Business Method Patents On the Internet. Retrieved January 3, 2006, from http://www.unc.edu/courses/2005spring/law/357c/001/projects/cmac/.

45. Wikipedia.org. Business Method Patents. Retrieved January 3, 2006, from http://en.wikipedia.org/wiki/Business_method_patent.

46. Wikipedia.org. Diamond V. Diehr. Retrieved January 3, 2006, from http://en.wikipedia.org/wiki/Diamond_v._Diehr.

47. Wikipedia.org. State Street Bank Decision. Retrieved January 3, 2006, from http://en.wikipedia.org/wiki/State_Street_Bank_decision.

48. Yoches, R. (2002). Business Method Patents: Where are we and Where are we going in Litigation? Journal of Internet Law. March. 